\title{
PENGARUH PENGALAMAN KERJA, SKEPTISME PROFESIONAL DAN \\ TEKANAN WAKTU TERHADAP KEMAMPUAN AUDITOR DALAM \\ MENDETEKSI FRAUD (STUDI EMPIRIS PADA \\ KANTOR AKUNTAN PUBLIK DI DIY)
}

\author{
Eko Ferry Anggriawan \\ Prodi Akuntansi Universitas Negeri Yogyakarta \\ eko.anggriawan@gmail.com
}

\begin{abstract}
Abstrak: Penelitian ini bertujuan untuk mengetahui pengaruh pengalaman kerja, skeptisme profesional dan tekanan waktu terhadap kemampuan auditor dalam mendeteksi fraud. Populasi dalam penelitian ini adalah seluruh auditor independen di Daerah Istimewa Yogyakarta yang berjumlah 133 orang. Teknik pengumpulan data pada penelitian ini menggunakan kuesioner. Jenis penelitian ini adalah penelitian asosiatif kausal. Jumlah sampel yang terkumpul adalah 45 orang. Teknik pengambilan sampel yang digunakan adalah covenience sampling. Hasil penelitian ini menunjukan bahwa: 1) Pengalaman Kerja berpengaruh positif terhadap Kemampuan Auditor dalam Mendeteksi Fraud. 2) Skeptisme Profesional berpengaruh positif terhadap Kemampuan Auditor dalam Mendeteksi Fraud. 3) Tekanan Waktu berpengaruh negatif terhadap Kemampuan Auditor dalam Mendeteksi Fraud. 4) Pengalaman Kerja, Skeptisme Profesional dan Tekanan Waktu secara bersama-sama berpengaruh terhadap Kemampuan Auditor dalam Mendeteksi Fraud.
\end{abstract}

Kata Kunci: Pengalaman Kerja, Skeptisme Profesional, Tekanan Waktu, Kemampuan Auditor, Mendeteksi Fraud.

Abstract: The purpose of the research is to know about work experience, professional skepticism and time pressure towards auditor's ability to detecting fraud. The population in this research are all independent auditor in DIY. Data collection techniques in this study is using questionnaires. The type of this research is a causal comparative. The number of samples collected was 45 people, sampling technique was used convenience sampling. These results indicate that: 1) work experience have positive effect towards auditor's ability to detecting fraud. 2) professional skepticism have positive effect towards auditor's ability to detecting fraud. 3) time pressure have negative effect towards auditor's ability to detecting fraud. 4) work experience, professional skepticism and time pressure have the effect towards auditor's ability to detecting fraud.

Keywords: Work Experience, Professional Skepticism, Time Pressure, Auditor's Ability, Detecting Fraud. 


\section{JURNAL NOMINAL / VOLUME III NOMOR 2 / TAHUN 2014}

\section{PENDAHULUAN}

Salah satu peran auditor eksternal adalah untuk memberikan keyakinan kepada pihak yang berkepentingan bahwa laporan keuangan telah disusun sesuai standar yang berlaku serta mencerminkan keadaan yang sebenarnya atas suatu entitas bisnis. Selain itu peran auditor eksternal adalah memastikan laporan keuangan tidak mengandung salah saji (misstatement) yang material baik yang disebabkan oleh kekeliruan atau kecurangan (fraud). Menurut standar audit, faktor yang membedakan kekeliruan dan kecurangan adalah tindakan yang mendasarinya, apakah kesalahan pada laporan keuangan terjadi karena tindakan yang disengaja atau tindakan yang tidak disengaja. Peran auditor adalah memeriksa laporan keuangan tersebut sehingga pemakai laporan keuangan akan percaya bahwa laporan keuangan tersebut tidak akan menyesatkan mereka

Kecurangan atau fraud semakin marak terjadi dengan berbagai cara yang terus berkembang sehingga kemampuan auditor dalam mendeteksi kecurangan juga harus terus ditingkatkan, bagaimanapun juga auditor dituntut untuk tetap mampu mendeteksi kecurangan seandainya terjadi kecurangan dalam melaksanakan tugas auditnya. Masalah yang timbul adalah auditor juga memiliki keterbatasan dalam mendeteksi fraud. Keterbatasan yang dimiliki auditor akan menyebabkan kesenjangan atau expectation gap antara pemakai jasa auditor yang berharap agar auditor dapat memberi keyakinan bahwa laporan keuangan yang disajikan tidak mengandung salah saji dan telah mencerminkan keadaan yang sebenarnya.

Setiap auditor memiliki kemampuan yang berbeda dalam mendeteksi kecurangan disebabkan karena beberapa faktor, misalnya tingkat pengalaman auditor yang berbeda, sikap skeptis yang berbeda dan situasi yang harus dihadapi auditor dalam bekerja yaitu adanya tekanan waktu.

Menurut Sucipto (2007) pengalaman adalah pengetahuan atau keahlian yang diperoleh dari suatu peristiwa melalui pengamatan langsung maupun berpartisipasi dalam peristiwa tersebut. Pengalaman akan mempengaruhi sensitivitas auditor terhadap isyarat-isyarat kecurangan.

Seseorang auditor dengan jam terbang yang tinggi serta biasa menemukan fraud dimungkinkan lebih teliti dalam mendeteksi fraud dibanding auditor dengan jam terbang yang rendah. Auditor yang berpengalaman adalah auditor yang mampu mendeteksi, memahami dan bahkan mencari penyebab dari munculnya kecurangan-kecurangan tersebut. Noviyani dan Bandi (2002), menyebutkan bahwa auditor yang berpengalaman akan memiliki pengetahuan tentang kekeliruan dan kecurangan yang lebih banyak sehingga akan menghasilkan kinerja yang lebih baik 


\section{JURNAL NOMINAL / VOLUME III NOMOR 2 / TAHUN 2014}

dalam mendeteksi kasus-kasus kecurangan dibandingkan dengan auditor yang tidak berpengalaman.

Kecurangan atau fraud itu sendiri frekuensi terjadinya jarang dan tidak semua auditor pernah mengalami kasus terjadinya kecurangan, sehingga pengalaman auditor yang berkaitan dengan kecurangan atau fraud tidak banyak. Auditor dengan pengalaman yang minim atau belum pernah menemukan fraud akan lebih sulit untuk mampu mendeteksi fraud dibandingkan dengan auditor dengan pengalaman banyak dan sudah pernah menangani kasus fraud. Auditor junior atau magang tentunya pengalaman yang dimiliki masih sangat minim, namun sebagai seorang auditor mereka juga diwajibkan untuk mampu mendeteksi adanya fraud walaupun tanggung jawab mereka lebih kecil dibanding auditor senior. Pengalaman merupakan faktor penting yang mempengaruhi kemampuan auditor dalam mendeteksi kecurangan. Pengalaman akan memberikan pelajaran terhadap jenis dan kecurangan-kecurangan yang pernah ditemukan auditor.

Sikap skeptisme profesional dianggap penting bagi seorang auditor dalam menilai bukti audit. Skeptisme adalah sikap kritis dalam menilai kehandalan asersi atau bukti yang diperoleh, sehingga dalam melakukan proses audit seorang auditor memiliki keyakinan yang cukup tinggi atas suatu asersi atau bukti yang telah diperolehnya dan juga mempertimbangkan kecukupan dan kesesuaian bukti yang diperoleh.

Skeptisme auditor yang rendah akan menyebabkan auditor tidak akan mampu mendeteksi adanya kecurangan karena auditor percaya begitu saja terhadap asersi yang diberikan manajemen tanpa mempunyai bukti pendukung atas asersi yang tersebut. Jika sikap skeptisme profesional yang dimiliki auditor tinggi, kemungkinan terjadinya kecurangan yang tidak terdeteksi semakin kecil. Semakin skeptis seorang auditor kemungkinan kemampuan untuk mendeteksi kecurangan juga semakin tinggi. Perbedaan ini menimbulkan masalah karena tanggung jawab auditor untuk mampu mendeteksi fraud adalah sama walaupun tingkat skeptisme mereka berbeda.

Tekanan waktu adalah ciri lingkungan yang biasa dihadapi auditor. Sososutikno (2003) mengemukakan tekanan anggaran waktu adalah situasi yang ditunjukan untuk auditor dalam melaksanakan efisiensi terhadap waktu yang telah disusun atau terdapat pembatasan waktu dan anggaran yang sangat ketat dan kaku.

Adanya tekanan waktu akan membuat auditor memiliki masa sibuk karena menyesuaikan tugas yang harus diselesaikan dengan waktu yang tersedia. 
Masalah akan timbul jika ternyata waktu yang direncanakan tidak sesuai dengan waktu yang yang dibutuhkan sebenarnya. Jika terjadi demikian seseorang akan mengabaikan hal-hal kecil yang dianggap tidak penting agar waktu yang direncanakan sesuai dengan yang dibutuhkan. Hal-hal kecil yang dilewatkan tentu akan mengurangi tingkat keyakinan auditor bahwa laporan keuangan yang di audit sesuai dengan yang sebenarnya, sehingga memungkinkan celah terjadinya kecurangan.

Seseorang yang bekerja dalam tekanan waktu maka tingkat keteletiannya akan berkurang dibanding orang yang bekerja tanpa tekanan. Penelitian oleh Braun (2000) dalam Koroy (2008: 29), mengilustrasikan salah satu efek dari tekanan waktu atas kinerja auditor dalam pendeteksian kecurangan, Braun menunjuk bahwa pengauditan dilaksanakan dalam suatu lingkungan multi tugas dimana auditor yang bekerja di bawah tekanan waktu, beberapa tugas akan lebih diprioritaskan dibandingkan tugas lainnya. Braun menguji hipotesisnya yaitu bila tekanan waktu ditingkatkan dalam lingkungan multi tugas, kinerja tugas yang lebih rendah/subsidiary (yaitu sensitivitas terhadap isyarat kecurangan) akan menurun sedangkan kinerja tugas yang dominan (mendokumentasi bukti) akan tetap tidak berubah. Hasil penelitian menunjukkan auditor yang berada di bawah tekanan waktu yang lebih akan kurang sensitif terhadap isyarat kecurangan sehingga kurang mungkin untuk dapat mendeteksi kecurangan. Dengan demikian auditor mungkin saja akan kehilangan bukti yang akan mempengaruhi hasil audit. Seorang auditor diharuskan untuk mampu bekerja di bawah tekanan waktu tanpa mengurangi kualitas kerjanya, namun pada kenyataannya tidak semua auditor mampu melaksanakan hal tersebut. Walaupun bekerja di bawah tekanan waktu seorang auditor harus dapat mendeteksi kecurangan dan bekerja secara profesional serta bertindak sesuai standar yang berlaku.

Kemampuan mendeteksi fraud adalah sebuah kecakapan atau keahlian yang dimiliki auditor untuk menemukan indikasi mengenai fraud. Menurut Kumaat (2011: 156) mendeteksi kecurangan adalah upaya untuk mendapatkan indikasi awal yang cukup mengenai tindak kecurangan, sekaligus mempersempit ruang gerak para pelaku kecurangan.

Menurut International Standards on Auditing (ISA) seksi 240 fraud didefinisikan sebagai tindakan yang disengaja oleh anggota manajemen perusahaan, pihak yang berperan dalam governance perusahaan, karyawan atau pihak ketiga yang melakukan pembohongan atau penipuan untuk memperoleh keuntungan yang tidak adil atau ilegal". Dua ketegori yang utama mengenai kecurangan 
adalah pelaporan keuangan yang curang dan penyalahgunaan aktiva (Arens, 2006: 430). Pelaporan keuangan yang curang adalah salah saji atau pengabaian jumlah atau pengungkapan yang disengaja dengan maksud menipu para pemakai laporan keuangan itu, sementara itu penyalahgunaan aktiva adalah kecurangan yang melibatkan pencurian aktiva entitas.

Dalam pendeteksian kecurangan, sebagian besar bukti-bukti kecurangan merupakan bukti-bukti yang sifatnya tidak langsung. Petunjuk adanya kecurangan biasanya ditunjukan oleh munculnya gejalagejala (symptoms) seperti adanya dokumentasi yang mencurigakan, keluhan dari pegawai ataupun kecurigaan dari teman sekerja. Pada awalnya kecurangan akan tercermin melalui timbulnya karakteristik tertentu atau yang biasa dikenal dengan red flag, baik yang merupakan kondisi atau keadaan lingkungan maupun perilaku seseorang.

Penyebab terjadinya fraud dikarenakan beberapa faktor, yaitu: 1) Tekanan (pressure) dimana individu tersebut mengalami tekanan untuk melakukan kecurangan. 2) Peluang (opportunity) yaitu situasi yang membuka kesempatan bagi manajemen atau pegawai untuk melakukan kecurangan. 3) Rasionalisasi atau kekurangan integritas (Ratinalization or lack of integrity) yaitu sikap atau karakter yang memperbolehkan manajemen atau pegawai untuk melakukan tindakan yang tidak jujur.

Tujuan penelitian ini adalah untuk mengetahui pengaruh pengalaman kerja, skeptisme profesional dan tekanan waktu terhadap kemampuan auditor independen di Daerah Istimewa Yogyakarta dalam mendeteksi fraud .

\section{METODE PENELITIAN}

\section{Jenis Penelitian}

Penelitian ini merupakan penilitian asosiatif kausal, dan jenis data yang digunakan dalam penelitian ini adalah data kuantitatif.

\section{Waktu dan Tempat Penelitian}

Penelitian dilakukan di tujuh KAP di DIY. Waktu penelitian dilaksanakan pada bulan Februari sampai dengan Maret 2014.

\section{Populasi dan Sampel Penelitian}

Populasi yang diambil peneliti adalah seluruh auditor independen di wilayah DIY yang berjumlah 133 orang. Teknik pengambilan sampel yang digunakan peneliti adalah convenience sampling. Dengan teknik tersebut diperoleh sampel sebanyak 45 responden.

Data, Instrumen, dan Teknik

\section{Pengumpulan Data}

Data yang diperoleh berupa jawaban responden atas kuesioner dari keempat 
variabel dalam penelitian ini. Instrumen yang digunakan untuk mengumpulkan data berupa kuesioner dengan skala likert. Responden akan memilih tingkat kesetujuannya dan ketidaksetuannya terhadap pertanyaan tertentu. Skala likert yang digunakan memiliki rentang nilai satu sampai dengan empat dengan asumsi untuk pertanyaan positif jawaban "Sangat Tidak Setuju" diberi skor 1, jawaban "Tidak Setuju" diberi skor 2, jawaban "Setuju" diberi skor 3 dan jawaban "Sangat Setuju" diberi skor 4. Untuk pertanyaan negatif maka skor dibalik menjadi jawaban "Sangat Tidak Setuju" diberi skor 4, jawaban "Tidak Setuju" diberi skor 3, jawaban "Setuju" diberi skor 2 dan jawaban "Sangat Setuju" diberi skor 1.

Berikut ini indikator yang digunakan untuk mengukur ketiga variabel dalam penelitin ini:

1. Kemampuan Auditor Mendeteksi Fraud

Indikator untuk mengukur variabel Kemampuan Auditor Mendeteksi Fraud mengadopsi dari penelitian Fullerton dan Durtschi (2004), yaitu:
a) Lingkungan Perusahaan
b) Catatan keuangan dan praktik akuntansi

2. Pengalaman Kerja

Indikator untuk mengukur variabel pengalaman kerja mengadopsi dari penelitian Suraida (2005: 119), yaitu:

a) Lamanya bekerja sebagai auditor

b) Banyaknya penugasan yang diselesaikan dalam satu tahun

c) Jenis perusahaan yang ditangani dalam satu tahun

3. Skeptisme Profesional

Indikator untuk mengukur variabel skeptisme profesional mengadopsi dari penelitian Hurt, Eining dan Plumee, yaitu:
a) Interogatif
b) Kehati-hatian mengambil keputusan
c) Rasa ingin tahu
d) Pemahaman interpersonal
e) Percaya diri
f) Keyakinan

\section{Tekanan Waktu}

Indikator untuk mengukur variabel tekanan waktu mengadopsi dari penelitian Nugraha (2012) dengan modifikasi, yaitu:

a) Tipe fungsional, menyatakan bahwa sikap auditor yang memanfaatkan waktu audit.

b) Tipe disfungsional, menyatakan sikap auditor untuk mengurangi perhatian terhadap aspek kualitatif dari indikasi salah saji. 


\section{JURNAL NOMINAL / VOLUME III NOMOR 2 / TAHUN 2014}

Teknik Analisis Data

Teknik analisis data yang dilakukan dalam penelitian ini adalah:

1. Statistik deskriptif untuk memberi gambaran terhadap objek yang diteliti melalui data sampel atau populasi (Sugiyono, 2010: 29) dan untuk melihat kecenderungan variabel.

2. Uji asumsi klasik yang terdiri atas beberapa pengujian, yaitu uji normalitas, uji heterokedastisitas, uji multikolinearitas, dan uji linearitas.

3. Uji hipotesis yaitu dengan regresi linear sederhana untuk $\mathrm{H} 1, \mathrm{H} 2$ dan H3 serta regresi liniear berganda untuk $\mathrm{H} 4$.

\section{HASIL}

\section{PENELITIAN}

DAN

\section{PEMBAHASAN}

Data pada penelitian ini dikumpulkan dengan cara menyebar kuesioner pada responden. Kuesioner yang disebar sebanyak 48. Kuesioner yang kembali sebanayak 45 kuesioner, dengan tingkat pengembalian $93,75 \%$. Uji validitas dan reliabilitas menggunakan sampel terpakai, sebanyak 30 responden. Ada beberapa item pernyataan yang tidak valid, sehingga harus dihapus dan tidak diikutsertakan dalam analisis selanjutnya. Keempat variabel dikatakan reliabel, karena menghasilkan nilai cronbach alpha>0,60. Setelah dilakukan uji asumsi klasik, diperoleh hasil bahwa data berdistribusi normal, tidak mengandung heterokedastisitas, tidak terjadi multikolinearitas, dan data linear, sehingga dapat dilakukan pengujian hipotesis.

\section{Hasil Penelitian}

\section{Pengalaman Kerja}

Data yang telah diperoleh dari kuesioner digolongkan kedalam kategori pengalaman kerja yang dibedakan menjadi tiga kategori, yaitu kategori tinggi, kategori sedang, dan kategori rendah. Berikut adalah tabel kategori kecenderungan pengalaman kerja:

Tabel 1. Kategori Pengalaman Kerja

No Kategori Interval Frek Persenta

\begin{tabular}{|c|c|c|c|c|}
\hline 1 & Tinggi & $X>9$ & 11 & $24,4 \%$ \\
\hline 2 & Sedang & $\begin{array}{c}6 \leq X \\
\leq 9\end{array}$ & 30 & $66,7 \%$ \\
\hline 3 & Rendah & $x<6$ & 4 & $8,9 \%$ \\
\hline \multicolumn{2}{|c|}{ Total } & & 45 & $100 \%$ \\
\hline
\end{tabular}

Sumber : data diolah

Dari tabel 1 dapat dilihat bahwa kategori pengalaman kerja mayoritas adalah sedang dengan presentase $66,7 \%$ atau sejumlah 30 responden. 
JURNAL NOMINAL / VOLUME III NOMOR 2 / TAHUN 2014

\section{Skeptisme Profesional}

Data yang telah diperoleh dari kuesioner digolongkan kedalam kategori skeptisme profesional yang dibedakan menjadi tiga kategori, yaitu kategori tinggi, kategori sedang, dan kategori rendah. Berikut adalah tabel kategori kecenderungan skeptisme profesional.

Tabel 2. Kategori Skeptisme Profesional

\begin{tabular}{|c|c|c|c|c|}
\hline No & Kategori & Interval & Frek. & $\begin{array}{c}\text { Persenta } \\
\text { se }\end{array}$ \\
\hline 1 & Tinggi & $X>33$ & 24 & $53,3 \%$ \\
\hline 2 & Sedang & $\begin{array}{l}22 \leq X \\
\leq 33\end{array}$ & 21 & $46,7 \%$ \\
\hline 3 & Rendah & $X<22$ & 0 & $0 \%$ \\
\hline \multicolumn{3}{|c|}{ Total } & 45 & $100 \%$ \\
\hline
\end{tabular}

Sumber : data diolah

Dari tabel 2 dapat dilihat bahwa kategori skeptisme profesional mayoritas adalah tinggi dengan presentase 53,3\% atau sejumlah 24 responden.

\section{Tekanan Waktu}

Data yang telah diperoleh dari kuesioner digolongkan kedalam tekanan waktu yang dibedakan menjadi tiga kategori, yaitu kategori tinggi, kategori sedang, dan kategori rendah. Berikut adalah tabel kategori kecenderungan tekanan waktu.

Tabel 3. Kategori Tekanan Waktu

\begin{tabular}{llccc}
\hline No & Kategori & Interval & Frek. & $\begin{array}{c}\text { Persenta } \\
\text { se }\end{array}$ \\
\hline 1 & Tinggi & $\mathrm{X}>18$ & 2 & $4,4 \%$ \\
2 & Sedang & $12 \leq \mathrm{X}$ & 43 & $95,6 \%$ \\
& & $\leq 18$ & & \\
3 & Rendah & $\mathrm{X}<15$ & 0 & $0 \%$ \\
& & 45 & $100 \%$ \\
\hline \multicolumn{7}{l}{ Total } & & &
\end{tabular}

Sumber : data diolah

Dari tabel 3 dapat dilihat bahwa kategori tekanan waktu mayoritas adalah sedang dengan presentase $95,6 \%$ atau sejumlah 43 responden.

\section{Kemampuan Auditor dalam Mendeteksi Fraud.}

Data yang telah diperoleh dari kuesioner digolongkan kedalam kemampuan auditor dalam mendeteksi fraud yang dibedakan menjadi tiga kategori, yaitu kategori tinggi, kategori sedang, dan kategori rendah. Berikut adalah tabel kategori kecenderungan kemampuan auditor dalam mendeteksi fraud. 
Tabel 4. Kategori kemampuan auditor dalam mendeteksi fraud

\begin{tabular}{llccc}
\hline No & Kategori & Interval & Frek. & $\begin{array}{c}\text { Persenta } \\
\text { se }\end{array}$ \\
\hline 1 & Tinggi & $\mathrm{X}>36$ & 36 & $80 \%$ \\
2 & Sedang & $24 \leq \mathrm{X}$ & 9 & $20 \%$ \\
& & $\leq 36$ & & \\
3 & Rendah & $\mathrm{X}<24$ & 0 & $0 \%$ \\
\cline { 3 - 4 } Total & & 45 & $100 \%$ \\
\hline
\end{tabular}

Sumber : data diolah

Dari tabel 4 dapat dilihat bahwa kategori kemampuan auditor dalam mendeteksi fraud mayoritas adalah tinggi dengan presentase $80 \%$ atau sejumlah 36 responden.

\section{Uji Hipotesis}

Hasil analisis regresi linier sederhana pengaruh pengalaman kerja terhadap kemampuan auditor dalam mendeteksi fraud dapat ditulis sebagai berikut:

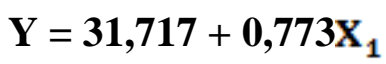

Dengan melihat persamaan tersebut dapat dilihat bahwa pengaruh pengalaman kerja terhadap kemampuan auditor dalam mendeteksi fraud adalah positif atau $\mathrm{H} 1$ diterima.

Hasil analisis regresi linier sederhana pengaruh skeptisme profesional terhadap kemampuan auditor dalam mendeteksi fraud dapat ditulis sebagai berikut:

$$
Y=13,701+0,715 X_{2}
$$

Dengan melihat persamaan tersebut dapat dilihat bahwa pengaruh skeptisme profesional terhadap kemampuan auditor dalam mendeteksi fraud adalah positif atau H2 diterima.

Hasil analisis regresi linier sederhana pengaruh tekanan waktu terhadap kemampuan auditor dalam mendeteksi fraud dapat ditulis sebagai berikut:

$$
Y=55,720-1,120 x_{3}
$$

Dengan melihat persamaan tersebut dapat dilihat bahwa pengaruh tekanan waktu terhadap kemampuan auditor dalam mendeteksi fraud adalah negatif atau H3 diterima.

Hasil analisis regresi linier berganda pengaruh tekanan waktu, skeptisme profesional dan tekanan waktu terhadap kemampuan auditor dalam mendeteksi fraud dapat ditulis sebagai berikut:

$Y=33,158+0,550 x_{1}+0,382 x_{2}-0,799 x_{3}$

Dari hasil perhitungan SPSS nilai signifikansi menunjukan hasil 0,000; karena nilai signifikansi lebih kecil dari 0,05 (0,000 $<0,05)$ maka pengaruh variabel pengalaman kerja, skeptisme profesional dan tekanan waktu terhadap kemampuan auditor dalam mendeteksi fraud secara simultan dapat dikatakan signifikan.

Dengan melihat persamaan tersebut dan signifikakansinya dapat dilihat bahwa 


\section{JURNAL NOMINAL / VOLUME III NOMOR 2 / TAHUN 2014}

variabel pengalaman kerja, skeptisme profesional dan tekanan waktu berpengaruh terhadap kemampuan auditor dalam mendeteksi fraud. dengan demikian $\mathrm{H} 4$ diterima

\section{Pembahasan}

Pengaruh Pengalaman Kerja terhadap Kemampuan Auditor dalam Mendeteksi Fraud

Hasil penelitian pengaruh pengalaman kerja terhadap kemampuan auditor dalam mendeteksi fraud mendukung hipotesis pertama yang menyatakan "Pengalaman kerja berpengaruh positif terhadap kemampuan auditor dalam mendeteksi fraud". Pengalaman kerja mempengaruhi $25,8 \%$ perubahan pada kemampuan auditor dalam mendeteksi fraud, sisanya sebesar $74,2 \%$ dipengaruhi oleh variabel lain diluar penelitian ini.

Hasil penelitian ini konsisten dengan hasil penelitian yang dilakukan Hafifah Nasution (2012) yang menyatakan bahwa pengalaman audit mempunyai pengaaruh positif terhadap kemampuan mendeteksi kecurangan. Penelitian Noviyani dan Bandi (2002) juga menyatakan bahwa adanya hubungan positif antara pengalaman audit dan pendeteksian kecurangan.

Libby dan Frederick (1990) dalam Hafifah (2012: 9) menyebutkan auditor yang berpengalaman tidak hanya memiliki kemampuan untuk menemukan kekeliruan atau kecurangan tetapi juga auditor tersebut dapat memberikan penjelasan yang lebih akurat dibanding auditor yang kurang pengalaman. Pengalaman kerja seorang auditor menyangkut lamanya bekerja menjadi auditor, banyaknya penugasan yang telah diselesaikan, dan banyaknya jenis perusahaan yang pernah ditangani (Suraida, 2005: 119). Semakin lama seseorang menjadi auditor, semakin banyak penugasan yang ditangani dan semakin banyak jenis perusahaan yang ditangani maka dapat dikatakan auditor tersebut semakin berpengalaman, pengalaman tersebut akan meningkatkan kesadaran auditor jika terjadi kekeliruan. Auditor yang berpengalaman juga akan lebih paham terkait penyebab kekeliruan yang terjadi, apakah karena murni kesalahan baik manusia atau alat ataukah kekeliruan karena kesengajaan yang berarti fraud.

\section{Pengaruh Skeptisme Profesional terhadap Kemampuan Auditor dalam Mendeteksi Fraud}

Hasil penelitian pengaruh skeptisme profesional terhadap kemampuan auditor dalam mendeteksi fraud mendukung hipotesis kedua yang menyatakan "Skeptisme profesional berpengaruh positif terhadap kemampuan auditor dalam mendeteksi fraud". Skeptisme profesional mempengaruhi $24,3 \%$ perubahan pada kemampuan auditor dalam mendeteksi 
fraud, sisanya sebesar $75,7 \%$ dipengaruhi oleh variabel lain diluar penelitian ini.

Hasil penelitian ini konsisten dengan penelitian yang dilakukan oleh Fullerton dan Durtschi (2004) yang menyatakan bahwa auditor dengan skeptisme tinggi akan meningkatkan kemampuan auditor dalam mendeteksi fraud. Semakin skeptis seorang auditor maka auditor akan lebih berhati-hati dalam membuat keputusan dengan cara mencari bukti atau informasi tambahan untuk mendukung kesimpulannya. Skeptisme profesional dicerminkan dengan sikap interogatif, kehati-hatian dalam mengambil keputusan, rasa ingin tahu, pemahaman interpersonal, percaya diri dan keyakinan dalam mengambil keputusan (Hurt et al, 2001: 17). Interogatif berarti auditor mempunyai sikap yang selalu mempertanyakan atas sesuatu yang terjadi, hati hati dalam mengambil keputusan berarti bahwa seorang auditor dalam mengambil keputusan merupakan keputusan yang paling tepat dan paling layak diambil, rasa ingin tahu berarti kemauan seorang auditor untuk memperoleh informasi yang dibutuhkan, pemahaman interpersonal berarti bahwa keinginan untuk memahami individu lebih mendalam, percaya diri berarti bahwa seorang auditor harus percaya terhadap kemampuan diri sendiri, yakin dalam mengambil keputusan berarti bahwa seorang auditor harus yakin akan setiap keputusan yang diambil atau dengan kata lain tidak mengaharap keberuntungan. Sikap tersebut harus dimiliki seorang auditor dalam pelaksanaan audit, sehingga auditor tidak percaya begitu saja terhadap asersi yang diberikan manajemen, namun auditor harus mampu menemukan bukti yang mendukung asersi tersebut. Apabila terjadi kecurangan, dengan sikap skeptis yang tinggi maka auditor lebih mungkin untuk menemukan kecurangan tersebut.

\section{Pengaruh Tekanan Waktu terhadap Kemampuan Auditor dalam Mendeteksi Fraud}

Hasil penelitian pengaruh tekanan waktu terhadap kemampuan auditor dalam mendeteksi fraud mendukung hipotesis ketiga yang menyatakan "Tekanan waktu berpengaruh negatif terhadap kemampuan auditor dalam mendeteksi fraud". Tekanan waktu mempengaruhi $29,2 \%$ perubahan pada kemampuan auditor dalam mendeteksi fraud, sisanya sebesar 70,8\% dipengaruhi oleh variabel lain diluar penelitian ini.

Hasil penelitian ini konsisten dengan penelitian yang dilakukan oleh Marleni Artika (2012) yang menyatakan bahwa tekanan waktu dalam melaksanakan audit mempengaruhi keberhasilan auditor dalam mendeteksi kecurangan. Auditor yang diberikan waktu terbatas dalam melaksanakan audit memiliki tingkat 
keberhasilan yang rendah dalam mendeteksi kecurangan.

Menurut Braun (2000) dalam Koroy (2008: 29) auditor yang bekerja di bawah tekanan waktu akan kurang sensitif jika terjadi kecurangan karena perhatian auditor terhadap penyebab salah saji akan berkurang, auditor akan lebih fokus ke dalam pekerjaan yang harus mereka selesaikan sehingga auditor gagal dalam menghasilkan sinyal-sinyal penyebab kecurangan.

Tekanan waktu yang dihadapi auditor akan direspon dengan dua tipe cara yaitu fungsional dan disfungsional. Tipe fungsional adalah perilaku auditor untuk bekerja lebih baik dan menggunakan waktu dengan baik sehingga kualitas auditnya dapat dipertahankan sementara tipe disfungsional adalah perilaku auditor yang membuat penurunan kualitas audit karena auditor lebih memprioritaskan tugas. Auditor dengan tipe fungsional tentu akan lebih mampu menemukan kecurangan dibanding auditor dengan tipe disfungsional karena tipe disfungsional kemungkinannya lebih besar untuk melewatkan bukti audit yang mengarah pada isyarat kecurangan.

\section{Pengaruh Pengalaman Kerja, Skeptisme}

Profesional dan Tekanan Waktu terhadap Kemampuan Auditor dalam Mendeteksi Fraud

Hasil penelitian ini mendukung hipotesis keempat yang menyatakan "Pengalaman kerja, skeptisme profesional dan tekanan waktu secara bersama-sama berpengaruh terhadap kemampuan auditor dalam mendeteksi fraud." pengalaman kerja, skeptisme profesional dan tekanan waktu mempengaruhi $52,2 \%$ perubahan terhadap kemampuan auditor dalam mendeteksi fraud sementara sisanya sebesar $47,8 \%$ dipengaruhi oleh variabel lain diluar penelitian ini.

Semakin berpengalaman seorang auditor maka semakin peka terhadap isyarat kecurangan karena seorang auditor yang berpengalaman sudah biasa tentang berbagai prosedur audit dan lebih paham jika terjadi potensi kecurangan (red flag).

Auditor yang mempunyai sikap skeptis tinggi maka lebih mungkin mendeteksi fraud dibanding yang mempunyai skeptis rendah, hal ini dikarenakan auditor yang mempunyai skeptis tinggi akan lebih berhati-hati dalam bertindak.

Tekanan waktu adalah keadaan dimana seorang auditor dituntut untuk melakukan efisiensi waktu dan menyelesaikan tugasnya dengan waktu tertentu yang telah dibuat atau direncanakan 
sebelumnya (Sososutikno, 2003). Semakin besar tekanan waktu yang dihadapi auditor maka kemampuan auditor dalam mendeteksi fraud semakin menurun.

\section{SIMPULAN DAN SARAN}

\section{Simpulan}

Berdasarkan data yang sudah diperoleh dan hasil analisis yang telah dilakukan, maka kesimpulan dari penelitian ini adalah:

1. Terdapat pengaruh positif antara pengalaman kerja terhadap kemampuan auditor dalam mendeteksi fraud. Hal ini dibuktikan dengan nilai signifikansi sebesar $0,000(0,000<0,05)$. Nilai koefisien regresi sebesar 0,773 yang mempunyai arah positif menunjukan bahwa semakin banyak pengalaman kerja seorang auditor maka kemampuan auditor dalam mendeteksi fraud juga semakin baik.

2. Terdapat pengaruh positif antara skeptisme profesional terhadap kemampuan auditor dalam mendeteksi fraud. Hal ini dibuktikan dengan nilai signifikansi sebesar $0,000 \quad(0,000<$ 0,05). Nilai koefisien regresi sebesar 0,715 yang mempunyai arah positif menunjukan bahwa semakin tinggi skeptisme seorang auditor maka kemampuan auditor dalam mendeteksi fraud juga semakin baik.
3. Terdapat pengaruh negatif antara tekanan waktu terhadap kemampuan auditor dalam mendeteksi fraud. Hal ini dibuktikan dengan nilai signifikansi sebesar $0,000(0,000<0,05)$. Nilai koefisien regresi sebesar -1,120 yang mempunyai arah negatif menunjukan bahwa semakin tinggi tekanan waktu yang dihadapi seorang auditor maka kemampuan auditor dalam mendeteksi fraud akan semakin menurun.

4. Terdapat pengaruh positif antara pengalaman kerja, skeptisme profesional dan pengaruh negatif antara tekanan waktu terhadap kemampuan auditor dalam mendeteksi fraud. Hal ini dibuktikan dengan nilai $\mathrm{F}$ hitung sebesar 17,027 dan nilai signifikansi 0,000. Nilai signifikansi yang kurang dari $0,05(0,000<0,05)$ dapat disimpulkan bahwa pengalaman kerja, skeptisme profesional dan tekanan waktu berpengaruh terhadap kemampuan auditor dalam mendeteksi fraud.

\section{Saran}

Berdasarkan hasil penelitian yang telah dilakukan, peneliti memberikan saran sebagai berikut:

1. Dalam mendeteksi fraud pengalaman seorang auditor sangat penting karena dengan pengalaman yang memadai auditor sudah terbiasa menghadapi 
sesuatu hal dalam sebuah proses audit dan lebih paham terhadap gejala terjadinya kecurangan (red flag), untuk itu pengalaman seorang auditor harus terus ditingkatkan misalnya dengan cara mengikuti pelatihan-pelatihan di bidang audit, selain itu para auditor junior lebih sering dilibatkan dalam tugas audit yang kompleks sehingga akan lebih berpengalaman dalam bidang audit.

2. Skeptisme profesional adalah sikap kehati-hatian dalam melaksanakan prosedur audit. Auditor yang kurang skeptis cenderung untuk percaya begitu saja terhadap asersi yang diberikan manajemen, hal ini tentu akan menyebabkan auditor tidak mampu mendeteksi adanya kecurangan karena auditor tidak mampu menemukan bukti yang mengarah pada kecurangan. Seorang auditor seharusnya mempunyai keyakinan yang tinggi terhadap kemampuan dirinya serta tidak mudah percaya begitu saja terhadap pernyataan yang diberikan orang lain, namun harus didukung dengan bukti yang kuat.

3. Tekanan waktu yang dihadapi auditor menyebabkan auditor akan lebih mempriorotaskan beberapa tugas jika waktu yang telah dianggarkan dirasa kurang, hal ini akan menurunkan perhatian auditor terhadap red flag. Supaya tidak terjadi demikian, dalam menganggarkan waktu audit seharusnya auditor

mempertimbangkan kompleksitas tugas dan tidak membuat anggaran waktu yang terlalu ketat dan terlalu longgar.

\section{DAFTAR PUSTAKA}

Abdul Halim. (2003). Auditing: DasarDasar Audit Laporan Keuangan. Yogyakarta: UPP AMP YKPN.

Arens , Alvin A., Randal J. Elder, Mark S. Beasley. (2006). Auditing and Assurance Services. 11th ed. New Jersey: Pearson Prentice Hall International.

Boynton, William C., Raymond N. Johnson. (2006). Modern Auditing: Assurance Services, and the Integrity of Financial reporting. 3rd ed. USA: Wiley.

Cristina Sososutikno. (2003). "Hubungan Tekanan Anggaran Waktu dengan Perilaku Disfungsional serta Pengaruhnya terhadap Kualitas Audit”. Jurnal Simposium Nasional Akuntansi VI.

Dermawan Wibisono. (2000). Riset Bisnis. Yogyakarta: BPFE.

Fullerton, Rosemary R., Cindy Durtschi. (2004). "The Effect of Professional Skepticsm on The Fraud Detection Skills of Internal Auditors". Jurnal Utah State University. 
H.M. Jogiyanto. (2007). Metodologi Penelitian Bisnis. Yogyakarta: BPFE.

Hafifah Nasution. (2012). "Pengaruh Beban Kerja, Pengalaman Audit dan Tipe Kepribadian Terhadap Skeptisme Profesional dan Kemampuan Auditor dalam Mendeteksi Kecurangan”. Tesis diterbitkan. Universitas Islam Negeri Syarif Hidayatulloh Jakarta.

Hall A. James dan Singleton Tommie. (2007). Audit dan Assurance Teknologi Informasi. Jakarta: Penerbit Salemba Empat.

Hutabarat, Goodman. (2012). "Pengaruh Pengalaman, Time Budget Pressure dan Etika Auditor terhadap Kualitas Audit”. Jurnal Ilmiah ESAI. Vol 6 No 1.

Icuk Rangga Bawono. (2010). "Faktor-

Faktor Dalam Diri Auditor dan Kualitas Audit: Studi pada KAP 'Big Four' di Indonesia”. Jurnal Simposium Nasional Akuntansi 13 Purwokerto.

Imam Ghozali. (2005). Aplikasi Analisis Multivariate dengan program SPSS. Semarang: Badan Penerbit Universitas Diponegoro.

Jaffar, Nahariah. (2009). "Fraud Detection: The Moderating Role of Fraud Risk Level”. Journal of Business and Public Affairs. Vol 3 Issue 1.
Louwers, Timothy J., dkk. (2008). Auditing \& Assurance Services. Third edition. New York: Mc Graw-Hill.

Ramos, Michael. (2003). “Auditor's Responsibility for Fraud Detection". Journal of Accountancy. Vol 195 No 1.

Singleton, Tommie, dkk. (2006). Fraud Auditing and Forensic Accounting. 3rd ed. USA: Wiley.

Sugiyono. (2007). Metode Penelitian Kuantitatif, Kualitatif, dan R\&D. Bandung: CV. Alfabeta.

Suharsimi Arikunto. (2006). Prosedur Penelitian Suatu Pendekatan Praktik. Jakarta: PT Adi Mahasatya. Sutrisno Hadi. (2004). Analisis Regresi. Yogyakarta: Yayasan Penerbitan Universitas Gadjah Mada

Suzy Noviyanti. (2008). "Skeptisme Profesional Auditor dalam Mendeteksi Kecurangan”. Jurnal Akuntansi dan Keuangan Indonesia. Vol 5 No 1.

Theodorus M. Tuanakotta. (2010). Akuntansi Forensik dan Audit Investigatif. Jakarta: Salemba Empat.

Tri Ramayana Koroy. (2008). "Pendeteksian Kecurangan (Fraud) Laporan Keuangan Oleh Auditor Eksternal". Jurnal Akuntansi dan Keuangan. Vol 10, No 1. 
Uma Sekaran. (2006). Research Methods for Business. Jakarta: Salemba Empat.

Valery, Kumaat G. (2011). Internal Audit. Jakarta: Erlangga.

Vinten, Gerald. (2005). "Managerial Auditing Journal”. Emerald Journal. Vol 20 No 3.

Whittington, O. Ray, Kurt Pany. (2010). Principles of Auditing \& Other Assurance Services. 7th ed. New York: Mc Graw-Hill. 